In any event, Eternal Shadows is a useful book, which should prove particularly helpful both to scholars and to students approching Yeats's theatre for the first time. Javier Torres not only manages, as Professor Anthony Roche ironically put it, "to talk on that most unfashionable and apparently contradictory of themes: W. B. Yeats as a man of the theatre"; he manages to do so with lucidity and insight.

Brian Hughes

\title{
Gordon McMullan and Jonathan Hope, eds. The Politics of Tragicomedy: Shakespeare and After. London: Routledge, 1992, 212 págs.
}

The Politics of Tragicomedy: Shakespeare and After is a collection of essays originally delivered as lectures at the meeting held at Wadham College in June of 1988 under the title of The Politics of Drama, 1610-1650. In its Preface and Introduction, the editors describe the purpose of this volume together with the criteria according to which the essays have been selected. The possibilities of characterizing tragicomedy not as a burlesque mixture of tragic/comic components, but rather as a self-defined genre, is the major concern leading G. McMullan and J. Hope to the publication of this Politics of Tragicomedy, where two fundamental objectives are accomplished. On the one hand, to gather together and make use of diverse standpoints regarding Renaissance politics and, on the other, to invite major professors and experts on this period to confer tragicomedy the literary status it deserves. Such an achievement will yield new, stimulating readings of the English drama written in the period between Shakespeare's last creative years and the creation of the Commonwealth. The term tragicomedy itself is thus subject to analysis, this volume covering all its established definitions, as well as the authorship of the model of tragicomedy unreliably attributed to John Fletcher.

All the essays collected share a common concern with political evolution as reflected in seventeenth-century theatre, looking for the key elements of political life between 1610 and 1650 in both the historical and social contexts and the role played by women in plays and audiences. The choice of these dates is by no means arbitrary: on the one hand, it obeys the editors' wish to study those Elizabethan strategies of drama distinct from Shakespeare's - thus reacting against New Historicism and its ineluctable dependence on his genius; on the other, it rescues all dramatic work yielded between 1642 and 1650, so far forgotten mostly due to the closure of theatres during that period. The aforesaid influence of social and historical contexts upon political evolution during the first half of the seventeenth century may be clearly observed in Lois Potter's and Martin Butler's essays. In "Topicality or Politics? The Two Noble Kinsmen, 1613-34," Potter examines the major topics of this play through a deep historical analysis and emphasizes the influence of social context when determining the political significance of The Two Noble Kinsmen. In his "Late Jonson," Butler focuses upon the last stages of Jonson's work -especially The New Inn - and shows how it reflects the parliamentary language of its time, and how the different themes handled lead this play to an ever-growing politization similar to that of the society which surrounded its author. 
Kathleen McLuskie's, Sophie Tomlinson's and Walter Cohen's essays study, from different standpoints, the role of women in the plays written between 1610 and 1650 . McLuskie and Tomlinson, in "“A Maidenhead, Amintor, at my Yeares': Chastity and tragicomedy in the Fletcher Plays" and "She That Plays the King: Henrietta Maria and the Threat of the Actress in Caroline Culture" respectively, coincide in their interest in studying in depth the role of women in audiences in Jacobean drama and its influence upon the progressive, privileged treatment of gender. Tomlinson, on the other hand, explores the concept of actress set forth in Caroline culture, according to which she analyses different plays-especially William Cartwright's The Lady Errant. Finally, Cohen's approach sets up a parallel between the social standard of women posited by the tragicomedies of this period and that of the working class in the literature of the Industrial Revolution: the mediating essence of the female character, which makes it easier for her lover to achieve political, monarchic power, is taken up again by the nineteenth-century working-man, whose co-ocurrence in the novel is unavoidable in order to achieve the hegemony of capital in England.

We will mention the essays by David Norbrook, Erica Sheen and Margot Heinemann all together, since, although they still share that common concern with the influence of social and political contexts, they also show certain special features which connect them to each other. Norbrook and Sheen contribute political readings of The Tempest and Cymbaline respectively. In “"What Cares These Roares for the Name of King?': Language and Utopia in The Tempest," Norbrook traces the dominant political voices of the play, from Guicciardini to Montaigne, thus advocating a rather Utopian reading of the The Tempest. In "“The Agent for His Master': Political Service and Professional Liberty in Cymbeline," Sheen argues that, in spite of the political conservatism traditionally associated with this play, Shakespeare makes his case against the absolutism of his age; furthermore, including Cymbeline in a general revolutionary frame, Sheen demystifies the common idea that Shakespeare accepted the cultural tenets of his age too readily. Heinemann's essay, on the other hand, seeks to unveil the social rootedness inherent in the tragicomedy of the first half of the seventeenth century, as well as widening Norbrook's concept of Utopia. The dénouements of these plays are, he argues, revealing enough. While popular theatre-Heinemann's major concern-have harsh, realistic endings, minority theatre conceals them behind Utopia in order to safeguard the reputation of social institutions and the hierarchical establishment.

Finally, we must note that although all the essays are interesting for their analysis of social, political and gender relationships of the seventeenth-century tragicomedy, Tomlinson's, Cohen's and Norbrook's are, we think, the most outstanding ones, especially due to both the originality of their approaches and the clarity of their expositions. 